\title{
DLST wt Allele
}

National Cancer Institute

\section{Source}

National Cancer Institute. DLST wt Allele. NCI Thesaurus. Code C126541.

Human DLST wild-type allele is located in the vicinity of $14 q 24.3$ and is approximately 22

$\mathrm{kb}$ in length. This allele, which encodes dihydrolipoyllysine-residue succinyltransferase

component of 2-oxog lutarate dehydrogenase complex, mitochondrial protein, is involved in both lysine degradation and the tricarboxylic acid cycle. 